\title{
COVERAGE OF FINANCING DEFICIT IN FIRMS IN FINANCIAL DISTRESS UNDER THE PECKING ORDER THEORY
}

\section{Sergio Sanfilippo-Azofra, Carlos López-Gutiérrez, Begoña Torre-Olmo}

\section{Introduction}

Capital structure has been a frequent topic in financial literature because it is one of the most important decisions a firm can make. Although many important contributions have been made in this area, most of the research does not include firms in financial distress, so the financing decisions adopted by these firms are still not well known. The financing decisions of those firms are very important because most of the strategy decisions such as investments, market entry, or product diversification are considerably affected by the financial constraints faced by them (Bowe, Filatotchev, \& Marshall, 2010).

Over the years, two main explanations for the capital structure of companies have been proposed (Barclay \& Smith, 2005; Flannery \& Rangan, 2006; Frank \& Goyal, 2009; Muradoğlu \& Sivaprasad, 2012). The first one is the static trade-off theory, which proposes a trade-off between the tax advantages of debt financing and the costs of financial distress. Too much debt can lead to financial distress and too little debt can give rise to low returns on equity. Therefore, companies select the capital structure that maximizes their value, which leads to an optimal debt level. The second one is the pecking order theory, which postulates the existence of a hierarchy of financial resources, so firms do not target optimum capital structures. When outside funds are necessary, firms can mainly resort to three sources: retained earnings, debt, and equity. Whereas retained earnings have no adverse selection problem, both equity and debt have an adverse selection risk premium because of information asymmetries between managers and investors. Investors demand higher returns on equity than on debt. Therefore, if companies do not have enough retained earnings to finance their investment project, they will prefer debt to equity.
Although these two theories have been tested using different methodologies, the evidence is controversial as the empirical results tend to support the predictions of both theories. Some studies highlight the importance of the pecking order theory and others show the relevance of the trade-off theory. In this regard, Shyam-Sunder and Myers (1999) find strong support for the pecking order theory when they analyze the relationship between net debt issued and financing deficit. Fama and French (2002) and Leary and Roberts (2005) show that firms' debt ratios adjust slowly or relatively infrequently toward their target, which is more consistent with the pecking order theory. Agca and Mozumdar (2004) and Lemmon and Zender (2010) propose a concave relationship between net debt issued and financing deficit, which enables a less strict financial hierarchy of the pecking order theory. On the other hand, several authors find evidence consistent with the trade-off theory (Cotei, Farhat, \& Abugri, 2011; Flannery \& Rangan, 2006; Frank \& Goyal, 2009). Besides, some studies tend to bear out both theories. Frank \& Goyal (2003) only find support for the pecking order theory among large firms, and Leary and Roberts (2005) show that both theories help explain some aspects of financing decisions. Finally, a lot of recent studies focus their attention on firms with different characteristics, such as small, large family controlled or diversified firms (González \& González, 2012; La Roccaa, La Roccaa, Geraceb, \& Smark, 2009; Pindado \& De la Torre, 2008; Selvarajah \& Ursel, 2012).

Most previous studies have analyzed the capital structure of healthy firms. However, the results of these studies are not directly applicable to firms in financial distress, mainly because these firms have overinvestment and underinvestment problems, less financial sources available and are affected by bankruptcy 
laws (Davydenko \& Franks, 2008; López, Torre, \& Sanfilippo, 2012; Gian \& Strahan, 2007). The little evidence about firms in financial distress is controversial, because the studies do not find support for the trade-off theory, but they do not provide conclusive results about the pecking order theory either. For example, Gilson (1997) finds that the high transaction costs borne by firms in financial distress prevent them from adjusting their capital structure to optimum levels. In this regard, Pindado, Rodrigues and De la Torre (2006), when analyzing a sample of small and medium-sized Portuguese firms, find that the financing decisions of firms in distress do not depend on their previous debt levels or on the existence of target debt ratios, and therefore do not support the trade-off theory. Liang and Bathala (2009) perform a study on a small sample of firms in financial distress in the United States, but their results are not very conclusive. They find that the firms' financing decisions did not seek an optimum debt ratio. However, they also find little support for the pecking order theory, as their results show a weak relationship between financing deficit and debt.

The trade-off theory proposes that firms pursue an optimal debt level by weighing the benefits of debt (especially debt-related tax shields) and the costs of debt (bankruptcy problems). However, many firms cannot quickly adjust their debt in response to changes in their target debt because they bear transaction costs. Firms in financial distress have a lot of trouble reaching their optimal capital structure proposed by the trade-off theory because they have high transaction costs (Asquith, Gertner, \& Scharfstein, 1994; Chou, Li, \& Yin, 2010). To reduce their debts, firms in financial distress must negotiate new payment terms with creditors or sell assets that implies complicated adjustments. To this regard, Gilson (1997) finds that distressed firms hardly ever manage to reduce their debt level in order to reach their optimal capital structure, so their debt ratios continue to be high. Another argument against the trade-off theory in firms in financial distress is that these firms cannot often take advantage of the debt-related tax shields. Financial distressed firms often incur losses, so they can seldom benefit from the tax deductibility of interest (Barclay \& Smith, 2005). Therefore, these firms find it quite hard to strike a balance between the advantages and disadvantages of debt financing.
The pecking order theory postulates the existence of a strict hierarchy of financial resources because of information asymmetries between managers and investors (Myers \& Majluf, 1984; Shyam-Sunder \& Myers, 1999). Firms would start using internal funds, then debt, and finally equity. However, the imposition of this strict hierarchy might not necessarily be applicable in firms in financial distress for two reasons: First, Shyam-Sunder and Myers (1999) suggest that these firms could cover their financing deficit by issuing equity or selling assets to avoid increasing their debt ratio and/or debt restructuring. Moreover, equity might be the only security that outside financiers or investors are willing to buy; second, Chirinko and Singha (2000) show how a hierarchy of debt and equity is not necessarily followed strictly when firms face a restriction on their debt capacity, a common situation for firms experiencing difficulties. All in all, firms in financial distress frequently have to use all of their available financial resources to cover their financing deficit and have more and more difficulties to issue debt. This implies that firms in financial distress increasingly turn to sources of funds other than debt issues as their financing deficit grows. Therefore, the relationship between net debt issued and financing deficit established by the pecking order theory cease to be linear and become concave quadratic. This quadratic relationship might well explain the controversy about the capital structure of firms in financial distress.

The main contribution of this study is to test a potential concave quadratic relationship between net debt issued and financing deficit in firms in financial distress, which has not been studied previously. If this quadratic relationship exists, the financing decisions of firms in financial distress will be different form the financing decisions of healthy firms, so the formers will not follow the strict financial hierarchy proposed by the pecking order theory due to their specific situation. Another important contribution of this study is that, different from previous research papers, we also analyze the probability of issuing equity. If firms in distress do not follow the strict hierarchy of the pecking order theory, a great probability of issuing equity can be expected than in healthy firms.

In this study we include healthy and distressed firms, so we are able to test the quadratic relationship in both sets of firms and 
compare their different financing behavior. Also, the methodology used allows us to overcome some limitations of previous studies. In the first analysis, the System GMM methodology of panel data is used, which enables controlling for the model's individual heterogeneity and the existence of potential problems of endogeneity. Subsequently, in the study of the probability of issuing equity, we use, for the first time in this kind of studies, a new Heterogeneous Choice Models (HCM) methodology developed by Williams (2009) applied to a logistic function. This methodology allows us to avoid the bias caused by the differences in the degree of residual variation between healthy firms and firms in financial distress. Previous studies do not consider those differences, so their results could be biased.

The analysis is performed on a sample of 3,337 listed firms from Germany, Canada, the United States, France, Italy and the United Kingdom from 1995 to 2006. The inclusion of these countries covers a broad spectrum of institutional environments. The sample period ends in 2006 to avoid the biases of the financial crisis. The results indicate a quadratic relationship between financing deficit and net debt issued for firms in financial distress. This relationship is concave, so that as the financing deficit increases, the net debt issuance proportion decreases. However, the financing decisions of healthy firms follow a linear relationship rather than a quadratic one. Finally, the second analysis shows that firms in financial distress have a greater probability of issuing equity, which supports our results regarding the existence of a concave quadratic relationship. Thus, equity financing could be an alternative to debt issuance as a source of funds for firms in financial distress.

The structure of the study is as follows: The sample used is described in Section 1. Section 2 presents the model and main results in relation to the existence of a quadratic relationship. It also describes the analysis of the probability of issuing equity and displays the results. We finish with the conclusions and the references.

\section{Sample and Data}

To test the existence of the quadratic relationship, we use a sample of non-financial firms listed on the stock exchange in Germany, Canada, the United States, France, Italy and the United Kingdom. The inclusion of these countries allows covering companies operating under different institutional environments with a broad spectrum of bankruptcy systems. This prevents that these circumstances condition the analysis by controlling for the country. For each country, we have an unbalanced panel of firms with information available for a minimum of seven consecutive years between 1995 and 2006. To calculate the second-order serial correlation test, fundamental for guaranteeing the robustness of the estimations made via the System GMM methodology, data for each company of at least four consecutive years is required. In addition, to calculate certain variables in our analysis, we required variables lagged three years. We restrict the sample period to end in 2006 so that our results are not affected by the financial crisis. After the onset of the financial crisis, the firms' financing behavior could be conditioned more by the availability of funds in the economy and the disruption of the financial systems than by the firms' situation, which could have given rise to a bias in our results. The economic-financial information for each firm is from the DataStream database, of the Thomson Financial Services group. The macroeconomic information is obtained from the World Bank's World Development Indicators database and OECD statistics.

Tab. 1 shows the temporal and country distribution of the firms for the six countries included in the analysis. By including only listed companies, the number of firms traded on each of the securities exchanges conditions the size by country. However, the table shows that the sample size, for all years and countries analyzed, is adequate for performing the analysis.

Since the financial distress situation is not directly observable, we employ two different proxy measures to distinguish the firms in financial distress.

First, we use the Z-Score model (Altman, 1968). The Z-Score model is:

$$
\begin{aligned}
& Z=1.2^{*} X 1+1.4^{*} X 2+3.3^{*} X 3+ \\
& +0.6^{*} X 4+1^{*} X 5
\end{aligned}
$$

where $\mathrm{X} 1$ is the working capital to total assets ratio; $X 2$ is the retained earnings to total assets ratio; $X 3$ is the earnings before interest and taxes to total assets ratio; X4 is the market value equity to book value of total liabilities ratio; $\mathrm{X} 5$ is sales to total assets ratio. 


\section{Tab. 1: Sample description}

Temporary distribution of the sample

\begin{tabular}{l|r|r|r|r|r|r|r}
\hline \multicolumn{1}{c|}{ Year } & Canada & \multicolumn{1}{c|}{ France } & Germany & \multicolumn{1}{c|}{ Italy } & \multicolumn{1}{c}{$\begin{array}{l}\text { United } \\
\text { kingdom }\end{array}$} & \multicolumn{1}{c}{ USA } & Total \\
\hline $\mathbf{1 9 9 5}$ & 76 & 119 & 161 & 47 & 311 & 789 & 1,503 \\
\hline $\mathbf{1 9 9 6}$ & 89 & 129 & 176 & 54 & 324 & 953 & 1,725 \\
\hline $\mathbf{1 9 9 7}$ & 97 & 133 & 183 & 59 & 344 & 1,056 & 1,872 \\
\hline $\mathbf{1 9 9 8}$ & 108 & 142 & 191 & 65 & 364 & 1,164 & 2,034 \\
\hline $\mathbf{1 9 9 9}$ & 153 & 147 & 202 & 70 & 443 & 1,353 & 2,368 \\
\hline $\mathbf{2 0 0 0}$ & 170 & 143 & 197 & 76 & 475 & 1,541 & 2,602 \\
\hline $\mathbf{2 0 0 1}$ & 186 & 234 & 252 & 113 & 506 & 1,585 & 2,876 \\
\hline $\mathbf{2 0 0 2}$ & 208 & 250 & 258 & 129 & 534 & 1,611 & 2,990 \\
\hline $\mathbf{2 0 0 3}$ & 199 & 245 & 246 & 129 & 519 & 1,519 & 2,857 \\
\hline $\mathbf{2 0 0 4}$ & 191 & 241 & 237 & 128 & 505 & 1,463 & 2,765 \\
\hline $\mathbf{2 0 0 5}$ & 187 & 223 & 234 & 123 & 489 & 1,424 & 2,680 \\
\hline $\mathbf{2 0 0 6}$ & 169 & 189 & 215 & 112 & 453 & 1,231 & 2,369 \\
\hline Total & $\mathbf{1 , 8 3 3}$ & $\mathbf{2 , 1 9 5}$ & $\mathbf{2 , 5 5 2}$ & $\mathbf{1 , 1 0 5}$ & $\mathbf{5 , 2 6 7}$ & $\mathbf{1 5 , 6 8 9}$ & $\mathbf{2 8 , 6 4 1}$ \\
\hline & & & & & & &
\end{tabular}

Observations per country

\begin{tabular}{|c|c|c|c|}
\hline \multirow{2}{*}{ Country } & \multicolumn{3}{|c|}{ Observations } \\
\hline & Total & Distressed Z-score & Distressed O-score \\
\hline Canada & 1,833 & 516 & 122 \\
\hline France & 2,195 & 436 & 149 \\
\hline Germany & 2,552 & 568 & 246 \\
\hline Italy & 1,105 & 429 & 80 \\
\hline United kingdom & 5,267 & 643 & 425 \\
\hline USA & 15,689 & 2,343 & 1,128 \\
\hline Total & 28,641 & 4,935 & 2,150 \\
\hline
\end{tabular}

Source: own

The value of Z-score has the following intervals. Values higher than 2.99 are considered the "safe zone", and it means that the possibility of company's bankruptcy is very low. Values between 1.81 and 2.99 are considered the "grey zone" or "zone of ignorance", because of the susceptibility to error classification. Values below 1.81 are considered "distress zone", and it means that the possibility of a company's bankruptcy is high. So, we identify firms in financial distress when they are situated in the "distress zone", when they have in a particular year a Z-score less than 1.81 .

Second, we use the O-Score to classify firms in financial distress (Ohlson, 1980). The O-Score is based on Ohlson's predicted bankruptcy probabilities $p$, following this specification:

$$
\begin{aligned}
& p=\frac{1}{1+e^{-y_{i t}}} \\
& y_{i t}=-1.32-0.407 * \text { SIZE }+6.03 * \\
& { }^{*} \text { TLTA }-1.43 * \text { WCTA }+0.757 * \\
& * \text { CLCA }-2.37 * \text { NITA }-1.83 * \\
& \text { FUTL }+0.285 * \text { INTWO }-1.72 * \\
& \text { OENEG }-0.521 \text { CHIN, }
\end{aligned}
$$

where SIZE is the log of total assets to GNP Price-level index ratio; TLTA is the total liabilities to total assets ratio; WCTA is the working capital to total assets ratio; CLCA is 
the current liabilities to current assets ratio; NITA is the net income to total assets ratio; FUTL is the funds from operations to total liabilities ratio; INTWO is equal to one in net income is negative in the previous 2 years or zero otherwise; OENEG is equal to one if total liabilities are greater than total assets or zero otherwise; $\mathrm{CHIN}=\frac{\mathrm{NI}_{\mathrm{t}}-\mathrm{NI}_{\mathrm{t}-1}}{\left|\mathrm{NI}_{\mathrm{t}}\right|-\left|\mathrm{NI}_{\mathrm{t}-1}\right|}$, where $\mathrm{NI}_{\mathrm{t}}$ is the
net income for year $\mathrm{t}$.

We identify firms in financial distress when the bankruptcy probability is greater than or equal to $50 \%$.

These two models have been widely used to identify firms in financial difficulties in both American and international studies (Dichev, 1998; Griffin \& Lemmon, 2002; Bhagat, Moyen, \& Suh, 2005; George \& Hwang, 2010; Lopez et al., 2012). On average, firms in financial distress represent $17 \%$ of the observations when we use the Z-Score model and $13 \%$ when we use the O-Score model.

\section{Empirical Analysis \\ 2.1 Methodology}

Shyam-Sunder and Myers (1999) present a test of the pecking order theory based on financing deficit under the premise that this deficit is covered entirely by issuing new debt. Thus they propose the following relationship:

$$
\Delta D_{\text {it }}=\alpha+\beta_{P O} D E F_{i t}+e_{i t}
$$

where $\Delta D_{i t}$ is the amount of net debt issued or withdrawn; $D E F_{i t}$ is the financing deficit; $e_{i t}$ is the random error term. According to Shyam-Sunder and Myers (1999), a simple version of the pecking order theory predicts $\alpha=0$ and $\beta_{\mathrm{PO}}=1$.

This method of assessing the Pecking order theory has been widely criticized (Frank \& Goyal, 2003; Leary \& Roberts, 2010). In the case of firms in financial distress, and according to Chirinko and Singha (2000), this model does not admit the possibility of simultaneously issuing debt and equity as we propose in this article. In this regard, Liang and Bathala (2009) find that the $\beta_{\mathrm{PO}}$ coefficient was positive and significant, but considerably lower than 1 in firms in financial distress. This result might well reflect that firms in financial distress cover their financing deficits not only with debt but with equity. In order to solve this problem, we will introduce the financing deficit square $\left(D^{2} F^{2}\right)$ into the equation (4):

$$
\Delta D_{\text {it }}=\alpha+\beta_{\text {PO }} D E F_{i t}+Y D E F^{2}{ }_{i t}+e_{i t}
$$

The use of a quadratic term allows testing not only the simultaneous issue of debt and equity, but also the existence of a hierarchy different to that proposed by the pecking order theory (Lopez et al., 2012). If firms in distress depend less on debts (and more on equity), or use debt issues decreasingly to cover their financing deficit, when this financing deficit increases, the $\beta_{\mathrm{PO}}$ coefficient in these firms would be positive, but considerably lower than 1 , and the $Y$ coefficient would be negative. Thus the percentage of debt issued to finance the financing deficit would decrease as this financing deficit increased.

As our study simultaneously analyzed healthy firms and those in financial difficulty, we modified equation (5) so that the model to be estimated would be as follows:

$$
\begin{aligned}
& \Delta D_{\text {it }}=\alpha+\left(\beta_{1}+\beta_{2} \text { DIF }_{i t}\right) D F_{i t}+ \\
& +\left(Y_{1}+Y_{2} \text { DIF }_{i t}\right) D^{2} F^{2}{ }_{i t}+\Sigma \rho_{j} \text { Country }_{i t}+ \\
& +\Sigma \lambda_{j} \text { Sector }_{i t}+\Sigma \varphi_{\mathrm{i}} \text { Year }_{\mathrm{it}}+\varepsilon_{\mathrm{it}} \text {, }
\end{aligned}
$$

where $\Delta D_{\text {it }}$ is the net debt issued to total assets (Frank \& Goyal, 2003; Lemmon \& Zender, 2010; Liang \& Bathala, 2009; Shyam-Sunder \& Myers, 1999); $D E F_{i t}$ is the financing deficit divided by total assets. This variable includes dividend payments, net investment and changes in working capital, and is reduced by operating cash flows after interests and taxes; DIF is a dummy variable that takes value 1 for firms in distress and 0 for healthy firms. For this, as we showed earlier, we followed two alternative approaches: the Altman Z-Score $\left(\mathrm{DIF}_{\mathrm{Z}}\right)$ and the Ohlson O-Score $\left(\mathrm{DIF}_{\mathrm{o}}\right)$. $\varepsilon_{\text {it }}$ represents the random error term. We also included dummy variables for country, year and sector.

The $\beta_{1}$ and $Y_{1}$ coefficients, respectively, show the linear and quadratic effects for healthy firms. The $\left(\beta_{1}+\beta_{2}\right)$ coefficients show the linear effect for firms in financial distress, and the $\left(Y_{1}+\right.$ $Y_{2}$ ) coefficients show the quadratic relationship for firms in distress. To test the significance of the $\left(\beta_{1}+\beta_{2}\right)$ and $\left(Y_{1}+Y_{2}\right)$ coefficients, it is necessary to perform a joint significance test under the null hypotheses $\mathrm{HO}: \beta_{1}+\beta_{2}=0$ and $\mathrm{HO}: Y_{1}+Y_{2}=0$. If firms in financial distress decreasingly used debt to cover their financing deficit as this financing deficit rises, $\left(\beta_{1}+\beta_{2}\right)$ can be expected to be positive and significant, 
but considerably less than 1 , and $\left(Y_{1}+Y_{2}\right)$ can be negative and significant.

To test the robustness of the analysis, we introduced the variables used by Frank and Goyal (2003) into the model (6), as proposed by Agca and Mozumdar (2004). This controls for other factors (apart from financing deficit) whose relevance has been demonstrated in previous studies of firm financing decisions. The resulting model would be as follows:

$$
\begin{aligned}
& \Delta D_{\text {it }}=a+\left(\beta_{1}+\beta_{2} D_{\text {If }}\right) D_{\text {it }} \mathrm{DEF}_{i \mathrm{t}}+ \\
& +\left(Y_{1}+Y_{2} D_{I F}\right) D E F^{2} \text { it it }+\beta_{3} \Delta T_{i t}+ \\
& +\beta_{4} \Delta \mathrm{MTB}_{\mathrm{it}}+\beta_{5} \Delta \mathrm{LS}_{\mathrm{it}}+\beta_{6} \Delta \mathrm{P}_{\mathrm{it}}+ \\
& +\Sigma \rho_{\mathrm{j}} \text { Country }_{i \mathrm{t}}+\Sigma \lambda_{\mathrm{j}} \text { Sector }_{\mathrm{it}}+ \\
& +\sum \varphi_{\mathrm{j}} \text { Year }_{\text {it }}+\varepsilon_{\text {it }} \text {, }
\end{aligned}
$$

where T refers to the tangibility of assets to total assets; MTB is the market-to-book ratio; LS is the natural logarithm of sales and $P$ is the return on assets.

Tab. 2 presents summary statistics for the sample. We estimated the models (6) and (7) using the generalized method of moments (System GMM). This method allows controlling for potential problems of endogeneity through the use of instruments, by including the lagged right-hand side variables.

\subsection{Results}

Tab. 3 shows the results of the analyses. In model (a), the Altman Z-Score was used to identify the firms in financial distress, while in model (b) the Ohlson O-Score was used.

In models (a) and (b), the quadratic term of the DEF variable was introduced. In the case of healthy firms, the DEF variable has a positive and significant coefficient, but considerably less than 1 . Therefore, the pecking order theory

\section{Tab. 2: Sample statistics}

\begin{tabular}{l|r|r|r|r} 
& \multicolumn{1}{|c|}{ Mean } & Standard deviation & \multicolumn{1}{c}{ Minimum } & \multicolumn{1}{c}{ Maximum } \\
\hline$\Delta \mathrm{D}$ & 0.0137 & 0.1108 & -0.9713 & 0.6989 \\
\hline $\mathrm{DEF}$ & -0.0351 & 0.1761 & -0.9877 & 2.4510 \\
\hline $\mathrm{DIV}$ & 0.0138 & 0.0215 & 0.0000 & 0.2970 \\
\hline $\mathrm{I}$ & 0.0691 & 0.0994 & -0.9310 & 0.8892 \\
\hline$\Delta \mathrm{WK}$ & 0.0078 & 0.1287 & -1.8135 & 1.3271 \\
\hline $\mathrm{CA}$ & 0.1258 & 0.1646 & -1.7118 & 1.1355 \\
\hline $\mathrm{T}$ & 0.3226 & 0.2318 & 0.0002 & 0.9968 \\
\hline MTB & 1.7125 & 1.2493 & 0.1845 & 19.1626 \\
\hline LS & 12.6820 & 2.0845 & 2.8865 & 19.2228 \\
\hline $\mathrm{P}$ & 0.0604 & 0.1237 & -0.9779 & 0.6554 \\
\hline$\Delta T$ & 0.0180 & 0.0957 & -0.9566 & 0.8456 \\
\hline$\Delta \mathrm{MTB}$ & -0.0347 & 0.9701 & -16.4099 & 14.4661 \\
\hline$\Delta$ LS & 0.0904 & 0.3254 & -4.8684 & 5.9904 \\
\hline$\Delta \mathrm{P}$ & -0.0009 & 0.0805 & -0.9131 & 0.9371 \\
\hline LIQ & 0.4898 & 0.2313 & 0.0032 & 0.9982 \\
\hline NDTS & -0.0013 & 0.0337 & -0.5281 & 0.6804 \\
\hline DEBT & 0.5313 & 0.1983 & 0.0054 & 0.9984 \\
\hline LOGSIZE & 5.5391 & 0.8878 & 2.8948 & 8.7543 \\
\hline
\end{tabular}

Source: own

Note: $\Delta \mathrm{D}$ is the net debt issued to total assets; DEF is the financing deficit divided by total assets; DIV is dividend payments to total assets; I is the net investment to total assets; CA refers to cash flow to total assets; $\Delta \mathrm{WK}$ is the change in working capital to total assets; T refers to the tangibility of assets to total assets; MTB is the market-to-book ratio; LS is the natural logarithm of sales; $P$ is the return on assets; LIQ refers to the current assets to total assets; NDTS is non-debt tax shields to total assets; DEBT is the leverage ratio; LOGSIZE is the logarithm of total assets. 
Tab. 3: Results (DIF variable non-lagged)

\begin{tabular}{|c|c|c|c|c|}
\hline & (a) & (b) & (c) & (d) \\
\hline DEF & $\begin{array}{c}0.1662 \text { ** } \\
(2.48)\end{array}$ & $\begin{array}{c}0.1641^{\text {** }} \\
(2.32)\end{array}$ & $\begin{array}{c}0.0953 \text { * } \\
(1.83)\end{array}$ & $\begin{array}{c}0.0613 \text { * } \\
(1.71)\end{array}$ \\
\hline $\mathrm{DEF}^{*} \mathrm{DIF}_{\mathrm{z}}$ & $\begin{array}{c}0.2713^{* *} \\
(2.36)\end{array}$ & & $\begin{array}{c}0.2995^{* * *} \\
(4.46)\end{array}$ & \\
\hline DEF * ${ }^{*} F_{0}$ & & $\begin{array}{c}0.2353^{* * *} \\
(2.73)\end{array}$ & & $\begin{array}{c}0.2142 \text { *** } \\
(3.63)\end{array}$ \\
\hline $\mathrm{DEF}^{2}$ & $\begin{array}{c}-0.0927 \\
(-0.67)\end{array}$ & $\begin{array}{c}-0.0413 \\
(-0.28)\end{array}$ & $\begin{array}{c}-0.0876 \\
(-0.96)\end{array}$ & $\begin{array}{l}0.0324 \\
(0.49)\end{array}$ \\
\hline$\left(\mathrm{DEF}^{*} \mathrm{DIF}_{\mathrm{z}}\right)^{2}$ & $\begin{array}{c}-0.1174 \\
(-0.95)\end{array}$ & & $\begin{array}{c}-0.1820 \text { * } \\
(-1.79)\end{array}$ & \\
\hline$\left(\mathrm{DEF}{ }^{*} \mathrm{DIF}_{\mathrm{o}}\right)^{2}$ & & $\begin{array}{c}-0.2470 \\
(-1.47)\end{array}$ & & $\begin{array}{c}-0.2517^{\text {*** }} \\
(-2.66)\end{array}$ \\
\hline$\Delta \mathrm{T}$ & & & $\begin{array}{c}0.4591^{* * *} \\
(6.24)\end{array}$ & $\begin{array}{c}0.5002 \text { *** } \\
(8.94)\end{array}$ \\
\hline$\triangle \mathrm{MTB}$ & & & $\begin{array}{l}0.0011 \\
(0.14)\end{array}$ & $\begin{array}{c}-0.0053 \\
(-1.37)\end{array}$ \\
\hline$\Delta \mathrm{LS}$ & & & $\begin{array}{c}0.0225 \\
(1.18)\end{array}$ & $\begin{array}{c}0.0053 \\
(0.6)\end{array}$ \\
\hline$\Delta \mathrm{P}$ & & & $\begin{array}{c}-0.2113^{* * *} \\
(-3.6)\end{array}$ & $\begin{array}{c}-0.0837^{*} \\
(-1.81)\end{array}$ \\
\hline CONS & $\begin{array}{l}0.0540 \\
(1.48)\end{array}$ & $\begin{array}{c}-0.0057 \\
(-0.25)\end{array}$ & $\begin{array}{c}-0.0083 \\
(-0.30)\end{array}$ & $\begin{array}{c}-0.0024 \\
(-0.31)\end{array}$ \\
\hline$\left(\beta_{1}+\beta_{2}\right)$ & $0.4375^{* * *}$ & $0.3994^{* * *}$ & $0.3949^{* * *}$ & $0.2755^{* * *}$ \\
\hline$\left(Y_{1}+Y_{2}\right)$ & $-0.2101^{* * *}$ & $-0.2883^{* * *}$ & -0.2696 *** & $-0.2192^{* * *}$ \\
\hline $\mathrm{m}_{2}$ & 0.951 & 0.452 & 0.171 & 0.12 \\
\hline HANSEN & $\begin{array}{l}74.26 \\
(0.179)\end{array}$ & $\begin{array}{l}104.57 \\
(0.194)\end{array}$ & $\begin{array}{c}151.4 \\
(0.131)\end{array}$ & $\begin{array}{l}263.47 \\
(0.212)\end{array}$ \\
\hline
\end{tabular}

Source: own

Note: Coefficients associated with each variable. In brackets, T-student; ${ }^{* * *}$ indicates a level of significance of 0.01 , ** indicates a level of significance of $0.05,{ }^{*}$ indicates a level of significance of $0.1 ; m_{2}$ is the 2nd order serial correlation statistic. Hansen is the over-identifying restriction test ( $p$-value in brackets). $\left(\beta_{1}+\beta_{2}\right)$ is the tests of joint significance under the null hypotheses $\mathrm{HO}: \beta_{1}+\beta_{2}=0$. $\left(Y_{1}+Y_{2}\right)$ is the tests of joint significance under the null hypotheses $\mathrm{HO}: Y_{1}+Y_{2}=0$. Time-dummy variables, country dummy variables and sector dummy variables are also included in the estimations although the results are not shown in the tables to focus on the main results obtained.

does not appear to have a higher explanatory power in the financing decisions adopted by the healthy firms in our sample. The $\mathrm{DEF}^{2}$ variable is not significant and therefore a quadratic model would not be suitable for these firms.

Regarding firms in financial distress, model (a) shows that the joint significance test $\left(\beta_{1}+\beta_{2}\right)$, under the null hypothesis $\mathrm{HO}: \beta_{1}+\beta_{2}=0$, is positive and significant. The joint significance test of the quadratic component $\left(Y_{1}+Y_{2}\right)$, under the null hypothesis $\mathrm{HO}: Y_{1}+Y_{2}$, is negative and significant. Therefore, unlike in healthy firms, a concave quadratic relationship can be observed in firms in financial distress. So, firms in financial distress would use debt decreasingly as their financing deficit increases. In fact, the linear coefficient is considerably less 1 , so the firms in financial distress in our sample did not strictly follow the pecking order theory. This coefficient, as we proposed, indicates that different financial resources are used to cover the financing deficit. Model (b) shows the same 
result, where the Ohlson O-Score was used to identify firms in distress. The test of the joint significance $\left(\beta_{1}+\beta_{2}\right)$ is positive and significant and $\left(Y_{1}+Y_{2}\right)$ is negative and significant.

In models (c) and (d), the Frank and Goyal variables (Frank \& Goyal, 2003) were introduced. In this case, the previous results were maintained since firms in financial distress show a concave quadratic relationship, whilst in healthy firms only a linear effect is observed. For the control variables introduced, $\Delta T$ coefficient is positive and significant, showing the usefulness of tangible assets as collateral to support greater level of leverage. As previous studies have shown greater profitability has a negative effect on leverage (Frank \& Goyal, 2003; Mackay \& Gordon, 2005).

To check the robustness of our results, the previous models were estimated again, introducing the DIF variable lagged one year. We used this to confirm the effect of financing deficit on net debt issued one year after a firm experiences financial distress. The results, not shown in this paper, are similar to those obtained in Tab. 3.

\subsection{Analysis of Equity Financing}

The results of the previous analysis show a concave quadratic relationship between net debt issued and financing deficit for firms in financial distress due to the fact that this deficit is covered by using different financial resources. As we explained earlier, the main source available to these firms might well be equity financing. If firms in distress do not follow the hierarchy of the pecking order theory, a great probability of issuing equity can be expected than in healthy firms. To test this idea, we propose a discrete choice analysis based on a logistic model in which the dependent variable takes value 1 if the firm issues equity and value 0 otherwise. However, the inclusion of two groups of firms (healthy and distressed) makes it very probable that the homoscedasticity of random errors will not be fulfilled because of the existence of differences in the degree of residual variation between both groups of firms. Unlike linear models, in non-linear models this fact gives rise to significant biases in the estimation of the model parameters (Yatchew \& Griliches, 1985). To overcome this problem in the current study, we performed an analysis using the Heterogeneous Choice Models (HCM) applied to a logistic function. These models control for the differences in the random error variance between the groups, which allows avoiding the biases in the estimations (Williams, 2009). The proposed model is as follows:

$$
\begin{aligned}
& \operatorname{Prob}(y=j)=\Lambda\left(x_{i} \beta / \exp \left(z_{i} Y\right)\right) \\
& x_{i} \beta=\alpha_{i}+\beta_{1 i} D_{I F}+\beta_{2 i} P_{i}+\beta_{3 i} \text { LIQ }_{i}+ \\
& +\beta_{4 i} \text { DIV }_{i}+\beta_{5 i} \text { NDTS }_{i}+\beta_{6 i} \text { DEBT }_{i}+ \\
& +\beta_{7 i} \text { LOGSIZE }_{i}+\beta_{8 i} \\
& \text { PE }_{i}+\Sigma \rho_{i} \text { Country }_{i}+\Sigma \lambda_{i} \text { Sector }_{i}+ \\
& +\Sigma \varphi_{i} \text { Year }_{i}+\varepsilon_{i},
\end{aligned}
$$

where $\Lambda$ (.) represents a logistic process; the dependent variable " $y$ " takes value 1 if there is a net increase in external equity of at least $5 \%$ of total assets, otherwise value 0 (Hovakimian, Opler, \& Titman, 2001; Leary \& Roberts, 2010; Vanacker \& Manigart, 2010); $z_{i}$ is a vector of variables used to determine the error variances linked to certain $Y$ parameters. To select the control variables included in $x_{i}$, previous studies on financing and equity issuance was followed (De Haan \& Hinloopen, 2003; De Jong \& Veld, 2001); DIF is a dummy variable that takes value 1 for firms in financial distress and 0 for healthy firms (as in previous analyses, the Altman Z-Score and Ohlson O-Score were used); $\mathrm{P}$ is the return on assets; LIQ refers to the current assets to total assets; DIV is dividend payments to total assets; NDTS is non-debt tax shields to total assets (Pindado et al., 2006); DEBT is the leverage ratio; LOGSIZE is the logarithm of total assets; PE is a dummy variable that takes value 1 if the firm has used equity financing during the previous year and 0 otherwise. We also included dummy variable for country, year and sector. Summary statistics of the variables is showed in Tab. 2 .

Tab. 4 shows the results of the analysis. Models (a) and (b), which include the variables without lags show that there is a greater probability of equity financing in firms in financial distress as the marginal effects of the DIF $_{z}$ and DIF $_{0}$ variables are positive and significant. These results support the existence of a concave relationship between the net debt issued and financing deficit obtained in the previous analysis. The absence of a strict financial hierarchy implies the simultaneous use of different sources of financing. This analysis demonstrates that equity financing could be an alternative to debt issuance as a source of funds for firms in financial distress as this would allow them to avoid excessive debt ratios or debt restructuring. 
With regard to the control variables, the results are similar to those of previous studies (De Haan \& Hinloopen, 2003; Vanacker \& Manigart, 2010). Profitability, liquidity, the leverage ratio and prior equity financing have a negative and significant effect on the probability of issuing equity, whilst firm size and non-debt tax shields have a positive influence on this probability. Like previous studies, dividends do not affect the probability of equity financing.

To check the robustness of our results, the previous models were estimated again, including all the variables lagged one period to avoid possible endogeneity problems (De Haan \& Hinloopen, 2003). The results, not shown in

\begin{tabular}{|c|c|c|c|c|c|c|}
\hline \multirow[b]{2}{*}{$\mathrm{DIF}_{z}$} & \multicolumn{3}{|c|}{ (a) } & \multicolumn{3}{|c|}{ (b) } \\
\hline & 0.0405 & $(8.25)$ & $* * *$ & & & \\
\hline $\mathrm{DIF}_{\mathrm{O}}$ & & & & 0.0201 & $(3.29)$ & $* \star *$ \\
\hline$P$ & -0.0483 & $(-7.09)$ & $* \star *$ & -0.0597 & $(-7.66)$ & $* * *$ \\
\hline LIQ & -0.0009 & $(-0.21)$ & & -0.0139 & $(-3.12)$ & $* * *$ \\
\hline DIV & -0.0306 & $(-0.61)$ & & -0.0567 & $(-1.09)$ & \\
\hline NDTS & 0.0734 & $(3.14)$ & *** & 0.0854 & $(3.61)$ & *** \\
\hline DEBT & -0.0511 & $(-9.43)$ & $* \star *$ & -0.0381 & $(-7.15)$ & *** \\
\hline LOGSIZE & -0.0049 & $(-3.93)$ & $* * *$ & -0.0042 & $(-3.23)$ & $* * *$ \\
\hline PE & 0.0981 & $(13.78)$ & $* * *$ & 0.1017 & $(14.07)$ & *** \\
\hline Pseudo $\mathrm{R}^{2}$ & 0.2128 & & & 0.2181 & & \\
\hline
\end{tabular}

Source: own

Note: Marginal effects (incremental effects for dummy variables) associated with each variable. In brackets, T-statistic; *** indicates significance at the $1 \%$ level, ${ }^{* *}$ indicates significance at the $5 \%$ level, ${ }^{*}$ indicates significance at the $10 \%$ level. Time-dummy variables, country dummy variables and sector dummy variables are also included in the estimations although the results are not shown in the tables to focus on the main results obtained.

this paper, are very similar to those obtained in Tab. 4, as firms in financial distress continue showing a greater probability of issuing equity.

\section{Conclusions}

This study focused on analyzing the financial decisions of firms in financial distress. A strict hierarchy of financing sources does not appear to be applicable in these firms. The study analyses the existence of a concave quadratic relationship between financing deficit and net debt issued, which provides additional evidence to previous research on the capital structure of firms experiencing financial difficulties.

The analysis was performed using a sample of 3,337 non-financial firms listed on the stock exchanges in Germany, Canada, the United
States, France, Italy and the United Kingdom during the period between 1995 and 2006 . The estimates were based on System GMM methodology of panel data, which makes it possible to control for endogeneity problems, and on HCM models applied to a logistic function, which control for the existence of differences in the degree of residual variation between healthy and distressed firms.

We found evidence that neither the tradeoff nor the strict hierarchy suggested by the pecking order theory would be applicable in firms in financial distress. Our results show that as financing deficit grows, these firms use debt decreasingly and have a greater probability of issuing equity. This leads to a concave quadratic relationship between financing deficit 
and net debt issued. This means that the costs of bankruptcy outweighs the benefits of debt related tax shields, so these firms attempt to avoid excessively increasing in their leverage ratios. Equity issuance can be very beneficial to firms in financial distress because it delays high debt level and gives them time to carry out the necessary operational and financial restructuring. Moreover, it can also alleviate the underinvestment behavior that arises from excessive debt levels and financial distress. However, we must bear in mind that on many occasions, firms in financial distress have no choice but to issue equity because equity might be the only security that outside financiers or investors are willing to buy when the debt levels are very high. Our results also reveal the pecking order theory is not the main reason behind financing decision in healthy firms. These firms seem to make their financing decisions based on both trade-off theory and pecking order theory. On the one hand, these firms are more likely to pursue an optimal debt level as our results show that they only cover a small proportion of their financing deficit using debt. On the other hand, healthy firms have less likelihood of equity issuance than firms in financial distress.

\section{References}

Agca, S., \& Mozumdar, A. (2004). Firm size, debt capacity, and the pecking order of financing choices (George Washington University Working paper). Retrieved from http:// papers.ssrn.com/sol3/papers.cfm?abstract id=687369.

Altman, E. I. (1968). Financial Ratios, Discriminant Analysis and the Prediction of Corporate Bankruptcy. The Journal of Finance, 23(4), 589-609. doi:10.1111/j.1540-6261.1968. tb00843.x.

Asquith, P., Gertner, R., \& Scharfstein, D. (1994). Anatomy of financial distress: An examination of junk-bond issuers. The Quarterly Journal of Economics, 109(3), 625-658. doi:10.2307/2118416.

Barclay, M. J., \& Smith, C. W. (2005). The Capital Structure Puzzle: The Evidence Revisited. Journal of Applied Corporate Finance, 17(1), 8-17. doi:10.1111/j.1745-6622.2005.012_2.x.

Bhagat, S., Moyen, N., \& Suh, I. (2005). Investment and internal funds of distressed firms. Journal of Corporate Finance, 11(3), 449-472. doi:10.1016/j.jcorpfin.2004.09.002.
Bowe, M., Filatotchev, I., \& Marshall, A. (2010). Integrating contemporary finance and international business research. International Business Review, 19(5), 435-445. doi:10.1016/j. ibusrev.2010.01.005.

Chirinko, R. S., \& Singha, A. R. (2000). Testing static tradeoff against pecking order models of capital structure: a critical comment. Journal of Financial Economics, 58(3), 417-425. doi:10.1016/S0304-405X(00)00078-7.

Chou, H., Li, H., \& Yin, X. (2010). The effects of financial distress and capital structure on the work effort of outside directors. Journal of Empirical Finance, 17(3), 300-312. doi:10.1016/j.jempfin.2009.12.005.

Cotei, C., Farhat, J., \& Abugri, B. A. (2011). Testing trade-off and pecking order models of capital structure: does legal system matter. Managerial Finance, 37(8), 715-735. doi:10.1108/03074351111146193.

Davydenko, S. A., \& Franks, J. R. (2008). Do bankruptcy codes matter? A study of defaults in France, Germany, and the UK. The Journal of Finance, 63(2), 565-608. doi:10.1111/j.15406261.2008.01325.x.

De Haan, L., \& Hinloopen, J. (2003). Preference hierarchies for internal finance, bank loans, bond, and share issues: Evidence for Dutch firms. Journal of Empirical Finance, 10(5), 661-681. doi:10.1016/S0927-5398(03)00010-0.

De Jong, A., \& Veld, C. (2001). An empirical analysis of incremental capital structure decisions under managerial entrenchment. Journal of Banking and Finance, 25(10), 1857-1895. doi:10.1016/S0378-4266(00)00163-1.

Dichev, I. D. (1998). Is the risk of bankruptcy a systematic risk? The Journal of Finance, 53(3), 1131-1147. doi:10.1111/0022-1082.00046.

Fama, E. F., \& French, K. R. (2002). Testing trade-off and pecking order predictions about dividends and debt. The Review of Financial Studies, 15(1), 1-33. doi:10.1093/rfs/15.1.1.

Flannery, M. J., \& Rangan, K.P. (2006). Partial adjustment toward target capital structures. Journal of Financial Economics, 79(3), 469-506. doi:10.1016/j.jineco.2005.03.004.

Frank, M. Z., \& Goyal, V. K. (2003). Testing the pecking order theory of capital structure. Journal of Financial Economics, 67(2), 217-248. doi:10.1016/S0304-405X(02)00252-0.

Frank, M. Z., \& Goyal, V. K. (2009). Capital structure decisions: Which factors are reliably important? Financial Management, 38(1), 1-37. doi:10.1111/j.1755-053X.2009.01026.x. 
George, T., \& Hwang, C. (2010). A resolution of the distress risk and leverage puzzles in the cross section of stock returns. Journal of Financial Economics, 96(1), 56-79. doi:10.1016/j.jfineco.2009.11.003.

Gilson, S. C. (1997). Transactions costs and capital structure choice: Evidence from financially distressed firms. The Journal of Finance, 52(1), 161-196. doi:10.1111/j.1540-6261.1997.tb03812.x.

González, V. M., \& González, F. (2012). Firm size and capital structure: evidence using dynamic panel data. Applied Economics, 44(36), 4745-4754. doi:10.1080/00036846.2011.595690.

Griffin, J. M., \& Lemmon, M. L. (2002). Book-to-market equity, distress risk, and stock returns. The Journal of Finance, 57(5), 2317-2336. doi:10.1111/1540-6261.00497.

Hovakimian, A., Opler, T., \& Titman, S. (2001). The debt-equity choice. Journal of Financial and Quantitative Analysis, 36(1), 1-24. doi:10.2307/2676195.

La Roccaa, M., La Roccaa, T., Geraceb, D., \& Smark, C. (2009). Effect of diversification on capital structure. Accounting and Finance, 49(4), 799-826. doi:10.1111/j.1467629X.2009.00304.x.

Leary, M., \& Roberts, M. (2005). Do firms rebalance their capital structure? Journal of Finance, 60(6), 2575-2619. doi:j.15406261.2005.00811.x.

Leary, M., \& Roberts, M. (2010). The pecking order, debt capacity, and information asymmetry. Journal of Financial Economics, 95(3), 332-355. doi:10.1016/j.jfineco.2009.10.009.

Lemmon, M., \& Zender, J. (2010). Debt Capacity and Tests of Capital Structure Theories. Journal of Financial and Quantitative Analysis, 45(5), 1161-1187. doi:10.1017/ S0022109010000499.

Liang, H., \& Bathala, C. (2009). Tradeoff or Pecking Order: Capital Structure Policy Suitable for Financially Distressed Firms. IUP Journal of Applied Finance, 15(10), 5-30.

López, C., Torre, B., \& Sanfilippo, S. (2012). Firms' performance under different bankruptcy systems: A Europe-USA empirical analysis. Accounting and Finance, 52(3), 849-872. doi:10.1111/j.1467-629X.2011.00407.x.

Mackay, P., \& Gordon, M. P. (2005). How Does Industry Affect Firm Financial Structure? The Review of Financial Studies, 18(4), 14331466. doi:10.1093/rfs/hhi032.
Muradoğlu, Y. G., \& Sivaprasad, S. (2012). Capital structure and abnormal returns. International Business Review, 21(3), 1-37. doi:10.1016/j.ibusrev.2011.03.007.

Myers, S. C., \& Majluf, N. S. (1984). Corporate financing and investment decisions when firms have information that investors do not have. Journal of Financial Economics, 13(2), 187-221. doi:10.1016/0304405X(84)90023-0.

Ohlson, J. A. (1980). Financial Ratios and the Probabilistic Prediction of Bankruptcy. Journal of Accounting Research, 18(1), 109-131. doi:10.2307/2490395.

Pindado, J., \& De La Torre, C. (2008). Financial decisions as determinants of ownership structure: Evidence from Spanish family controlled firms. Managerial Finance, 34(12), 868-885. doi:10.1108/03074350810915824.

Pindado, J., Rodrigues, L., \& De La Torre, C. (2006). How does Financial Distress Affect Small Firms' Financial Structure? Small Business Economics, 26(4), 377-391. doi:10.1007/s11187-005-4845-8.

Qian, J., \& Strahan, P. E. (2007). How laws and institutions shape financial contracts: The case of bank loans. The Journal of Finance, 62(6), 2803-2834. doi:10.1111/j.15406261.2007.01293.x.

Selvarajah, E., \& Ursel, N. (2012). Mergers and corporate debt financing. Economics Letters, 114(3), 296-298. doi:10.1016/j. econlet.2011.11.003.

Shyam-Sunder, L., \& Myers, S. C. (1999). Testing static tradeoff against pecking order models of capital structure. Journal of Financial Economics, 51(2), 219-244. doi:10.1016/ S0304-405X(98)00051-8.

Vanacker, T., \& Manigart, S. (2010). Pecking order and debt capacity considerations for high-growth companies seeking financing. Small Business Economics, 35(1), 53-69. doi:10.1007/s11187-008-9150-x.

Williams, R. (2009). Using heterogeneous choice models to compare logit and probit coefficients across groups. Sociological Methods and Research, 37(4), 531-559. doi:10.1177/0049124109335735.

Yatchew, A., \& Griliches, Z. (1985). Specification Error in Probit Models. The Review of Economics and Statistics, 67(1), 134-139. doi:10.2307/1928444. 
Ass. Prof. Sergio Sanfilippo-Azofra, Ph.D. University of Cantabria

Faculty of Business and Economics Business Administration Department sanfilis@unican.es

Ass. Prof. Carlos López-Gutiérrez, Ph.D. University of Cantabria Faculty of Business and Economics Business Administration Department carlos.lopez@unican.es

Ass. Prof. Begoña Torre-Olmo, Ph.D. University of Cantabria Faculty of Business and Economics Business Administration Department torreb@unican.es 


\section{Abstract}

\section{COVERAGE OF FINANCING DEFICIT IN FIRMS IN FINANCIAL DISTRESS UNDER THE PECKING ORDER THEORY}

\section{Sergio Sanfilippo-Azofra, Carlos López-Gutiérrez, Begoña Torre-Olmo}

The financing decisions adopted by firms in financial distress are very important because most of the strategy decisions such as investments, market entry, or product diversification are considerably affected by the financial constraints faced by them. However, these decisions are still not well known and empirical evidence about firms in financial distress is controversial. Previous studies do not find support for either the trade-off theory or the pecking order theory, which explain the financial decisions of healthy firms. Distressed firms frequently have to use all of their available financial resources to cover their financing deficit. This could give rise to a concave quadratic relationship between financing deficit and net debt issued, which might well explain the ambivalent results about the financial decisions of these firms. To analyze this quadratic relationship, which has not been studied previously, we perform an empirical analysis on a sample of 3,337 listed firms from Germany, Canada, the United States, France, Italy and the United Kingdom. Our results show that the pecking order theory does not appear to have a higher explanatory power in healthy firms. Moreover, the hierarchy suggested by the pecking order theory is not totally applicable in firms in financial distress. Our results show that as financing deficit grows, these firms use debt decreasingly, which gives rise to a concave quadratic relationship between financing deficit and net debt issued. This suggests that firms in financial distress have difficulty issuing new debt. Our results also show that firms in financial distress have a greater probability of issuing equity. Therefore, these firms can use equity financing as an alternative to debt issuance.

Key Words: Capital structure, financial distress, pecking order.

JEL Classification: G32, G33.

DOI: 10.15240/tul/001/2016-4-008 